\title{
ANALISIS EFEKTIVITAS SISTEM INFORMASI PENGADAAN BARANG DAN JASA PADA PT. TELKOMSEL BRANCH MATARAM
}

\author{
Reny Wardiningsih ${ }^{1}$, Koko Sasongko ${ }^{2}$ \\ STMIK Mataram ${ }^{1}$ \\ Universitas Mataram² \\ reny.wardi@yahoo.com
}

\begin{abstract}
Abstrak - Penelitian ini bertujuan untuk mengetahui efektivitas sistem informasi pengadaan barang dan jasa pada PT Telkomsel Branch Mataram. Metode yang digunakan adalah Deskriptif analitis. Sampel dalam penelitian ini ada dua yakni; (1) sebanyak 45 orang karyawan tetap pengguna system informasi (2) Struktur Organisasi, SOP, BAK, FPB, BAST, Invoice. Teknik pengumpulan data menggunakan kuesioner dan wawancara; SOP Flowchart dan e-procurement. Teknik evaluasi data (system Informasi) yang digunakan adalah: (1) Mengidentifikasi tujuan sistem informasi tersebut; (2) Memilih ukuran yang digunakan; (3) Mengidentifikasikan sumber-sumber data; (4) Menentukan nilai ex ante sebagai ukuran; (5) Menentukan nilai ex post sebagai ukuran; (6) Mengidentifikasi dampak system. Hasil Penelitian ini menunjukkan bahwa (1) sistem pengadaan yang berjalan sudah menggunakan sistem e-procurement dan telah sesuai dengan SOP. Dari perbandingan tersebut dapat diketahui bahwa pada PT.Telkomsel Branch Mataram menggunakan metode sistem tender. Hal ini juga dibuktikan dengan adanya dokumentasi dari data BAK, FPB, BAST serta invoice yang menunjukan bahwa perusahaan ini menggunakan vendor dalam proses pengadaan barang dan jasa. Dari uraian diatas dapat disimpulkan bahwa e-procurement yang ada pada PT. Telkomsel Branch Mataram telah berjalan dengan efektif. Hasil penelitian ke (2) Dampak penggunaan sistem yang berjalan memberikan kemampuan melacak seberapa besar penyerapan budget yang telah dilakukan Branch Mataram, apakah telah sesuai target budget yang di anggarkan atau belum mencapai target.
\end{abstract}

Kata Kunci : Efektivitas, Sistem Informasi, Pengadaan Barang dan Jasa

\section{LATAR BELAKANG}

Saat ini dunia bisnis pertelekomunikasian berkembang sangat pesat. Pertumbuhan bisnis komunikasi yang luar biasa ini memunculkan ungkapan bahwa telekomunikasi merupakan hal yang sangat vital dalam kehidupan sehari-hari, oleh karena itu telekomunikasi sangat diperlukan. Untuk medukung aktivitas usaha telekomunikasi ini perlu adanya informasi yang memadai. Informasi yang cepat, tepat dan dapat dipercaya sangat diperlukan pihak manajemen dalam rangka pengambilan keputusan untuk mengelola dan mengawasi perusahaan. Informasi tersebut dapat diperoleh apabila didukung oleh suatu informasi yang baik dan efektif. Hal ini didukung oleh pernyataan O'Brein (2006:10) bahwa peranan dasar sistem informasi dalam bisnis adalah (1) mendukung proses dan operasi bisnis, (2) mendukung pengambilan keputusan para pegawai dan manajernya, (3) mendukung strategi untuk keunggulan kompetitif (Maslija 2016).

Ada beberapa keriteria yang dapat dijadikan acuan bagi manajemen dalam menilai apakah sistem yang ada telah berjalan dengan efektif. Efektivitas dimaksudkan bahwa produk akhir suatu kegiatan (operasi) telah mencapai tujuannya, baik ditinjau dari segi kualitas hasil kerja, kuantitas hasil kerja, maupun target batas waktu. Dari pengertian di atas kita dapat menilai efektivitas sistem dari segi kualitas hasil kerja, kuantitas hasil kerja, dan target batas waktu. Selain itu, Mecleod (2001:350) menyatakan bahwa kriteria-kriteria yang perlu diperoleh untuk menilai apakah sistem yang ada atau yang akan dibuat efektif dan efisien adalah 1) Relevant, 2) Capacity of system, 3) Efficient, 4) Timeliness, 5) Accessibility , 6) Flexibility , 7) Accurate , 8) Reliability , 9) Security of system , 10) Economics , 11) Simplicity .

Setiap perusahaan telekomunikasi tentunya juga memiliki kebutuhan untuk menunjang kegiatan promosi maupun kegiatan lain dalam perusahaan. Kebutuhan tersebut yakni pengadaan barang dan jasa. Hal itu guna meningkatkan kualitas performa perusahaan atau menunjang keberadaan Sumber Daya Manusia (SDM) yang ada di perusahaan tersebut. Mempermudah proses dari pengadaan barang dan jasa itu, tiap perusahaan memiliki cara yang berbeda-beda, yakni merancang bagaimana cara agar proses pengadaan barang dan jasa tersebut berjalan dengan baik, sehingga apa yang telah di rencanakan menjadi efektif. Dan setelah semua rancangan di buat maka terbentuklah suatu ketentuan atau standar yang di gunakan untuk melakukan kegiatan tersebut secara berulang-ulang yang biasa di sebut Standart Operational Procedure (SOP) yang nantinya akan di jadikan acuan untuk tiap pelaksanaan proses pengadaan barang dan jasa. Dalam proses inilah, dibutuhkan peran bagian pengadaan untuk dapat memenuhi kebutuhan akan barang dan jasa sesuai dengan kualitas, jumlah, waktu, tempat, harga dan sumber yang tepat.

PT. Telkomsel (Telekomunikasi Seluler) adalah anak perusahaan dari PT Telkom, yang $40 \%$ sahamnya juga dipegang oleh perusahaan telekomunikasi dari Singapura yakni Singtel. Perusahaan ini adalah salah satu perusahaan telekomunikasi terkemuka di Indonesia. PT Telkomsel memiliki lebih dari 30 cabang di seluruh Indonesia, tiap cabang dari PT. Telkomsel tersebut biasa di kenal dengan sebutan "Branch". Dan salah satu cabang PT. Telkomsel yang ada di kota Mataram adalah Branch Mataram. Bisnis PT Telkomsel adalah consumer solutions sebagai penyedia jaringan seluler dual band melalui kartu prabayar (simPATI, Kartu Facebook, Kartu As Lombok dan Kartu Telkomsel Flash) serta pasca bayar (HALO). Dalam hal ini yang termasuk dalam pengadaan barang dan jasa adalah kegiatan promosi yang di lakukan untuk memasarkan produk tersebut kepada konsumen. Pengadaan barang dan jasa yang di maksud adalah komponen-komponen pelengkap yang di 
perlukan untuk membantu tercapainya tujuan promosi seperti materi promo ( $x$-banner, adlibs radio, materi baligho, materi billboard, spanduk dan flayer) yang tergolong dalam katergori pengadaan barang dan vendor (event organizer dan SPG) sebagai kategori pengadaan jasa. Dalam hal ini pengadaan "barang" dan "jasa" adalah dua komponen yang tidak dapat dipisahkan pada proses pelaksanaannya. Karena sudah menjadi satu kesatuan sesuai dengan Keputusan Direksi (KD).

Dalam melakukan proses pengadaan barang dan jasa pada PT Telkomsel Branch Mataram diharuskan untuk menunjuk pihak ke-3 (dalam hal ini disebut vendor) dalam melakukan kegiatan promosi atau event. Setiap pengadaan barang dan jasa yang di lakukan di perusahaan ini harus mendapat persetujuan dari pejabat yang berwenang, seperti pengadaan dengan nominal kurang dari lima ratus juta rupiah yang harus mendapat persetujuan dari pihak General Manager User (GM User) dan General Manajer Pengadaan (GM Pengadaan). Dana yang di gunakan untuk pengadaan nantinya juga berasal dari Regional (Bali), bukan dari Branch Mataram. Jadi fungsi dari divisi finance pada Branch Mataram hanyalah sebagai perantara, padahal di Branch Mataram juga memiliki budget untuk pengadaan barang dan Jasa.

Proses pengadaan barang dan jasa, divisi marketing pada PT Telkomsel Grapari Mataram tidak diperbolehkan untuk memegang dana langsung dari divisi finance, melainkan melalui perantara pihak ke-3 (dalam hal ini disebut vendor) yang akan menjalankan kegiatan promosi sekaligus menagihkan invoice ke divisi finance. Dengan kata lain, vendor yang akan terlebih dahulu menanggulangi pembiayaan selama promo atau event berjalan. Sesuai dengan KD PT Telkomsel, untuk menunjuk vendor perlu di lakukan beberapa tahap, yaitu (1) Planning, (2) Purchasing dan (3) Paying. Tahap Planning yakni langkah awal bagi divisi marketing untuk merencanakan program kerja dan berapa jumlah pengeluaran yang nantinya akan di keluarkan dalam program yang akan di jalankan bersama vendor nantinya. Tahap ke-2 yaitu Purchasing, adalah tahap penentuan siapa yang akan menjadi vendor. Untuk itu PT Telkomsel melakukan tender terhadap beberapa kandidat yang dirasa sanggup memenuhi kriteria sebagai vendor. Setelah di temukan siapa pemenangnya maka akan di lakukan negosiasi harga kepada pihak yang terkait. Tahap akhir dalah proses pembayaran atau Paying yang akan di laksanakan apabila pihak ke-3 telah selesai melakukan tugas yang di berikan oleh divisi marketing serta tidak lupa untuk mengajukan invoice kepada divisi finance PT Telkomsel Branch Mataram agar uang yang di gunakan untuk pelaksanaan event diganti dan fee vendor dapat segera cair (fee Event Organizer/ Vendor $5 \%$ dari total budget pengeluaran selama event).

Penelitian Maslija (2016) menunjukkan system informasi pengadaan barang dan jasa berjalan efektif dipengaruhi oleh proses distribusi yang memiliki sistem pengawasan yang baik terhadap ketersediaan stock yg ada sehingga tidak terjadi kekurangan dan kelebihan stock pada gudang. Hal ini didukung oleh Rahayu (2015) menunjukkan system informasi sudah berjalan efektif pada PT BPR Syariah Puduarta Insani Tembung, namun sistem yang digunakan dalam pengolahan data masih terjadi keterlambatan status mutakhir dari data-data di dalam file induk aplikasi, meski sudah sangat pendek periodenya, yakni harian. Selanjutnya penelitian ini didukung oleh penelitian Nanoka (2014); Tanesia (2015); Swadesi (2017).

Dari uraian diatas peneliti melakukan penelitian "Analisis Efektivitas Sistem Informasi Pengadaan Barang dan Jasa pada PT.Telkomsel Branch Mataram". Ada beberapa hal yang membuat peneliti tertarik, yakni 1) Fenomena bahwa masih ada beberapa BUMN yang belum menerapkan sistem e-procurement dan 2) Memastikan apakah pada PT Telkomsel Branch Mataram sudah menerapkan system eprocurement dan apakah telah berjalan dengan efektif.

\section{Tujuan Penelitian}

Penelitian ini bertujuan untuk mengetahui Efektivitas Sistem Informasi Pengadaan Barang dan Jasa pada PT Telkomsel Branch Mataram.

\section{KAJIAN PUSTAKA \\ Pengadaan}

Pengadaan adalah perolehan atau pembelian barang dan jasa untuk mencapai tujuan suatu organisasi. Hal ini dirasa sangat menguntungkan karena dapat meningkatkan kualitas dan kuantitas terhadap kepuasan konsumen. Perusahaan dan badan publik sering menggunakan pengadaan untuk melakukan persaingan promosi yang sehat dan terbuka untuk bisnis mereka guna meminimalkan penipuan dan kolusi. Berikut langkah-langkah dalam proses pengadaan :

a. Mengakui adanya kebutuhan akan barang dan jasa

b. Memenuhi syarat pengadaan secara spesifik

c. Melibatkan pemasok (vendor) yang potensial

\section{Pengadaan Elektronik (E-Procurement)}

Pengembangan e-procurement dimulai pada akhir tahun 1990-an, dan hal ini dianggap lebih baik dan fleksibel oleh negara-negara besar di Amerika dibandingkan dengan pengadaan tradisional yang dahulu mereka terapkan. Perusahaan-perusahaan seperti Bayer AG, Cisco Systems Inc, SAP AG dan Xerox (Europe) Ltd adalah beberapa di antara perusahan besar di dunia yang telah menerapkan sistem e-procurement. Menurut Puschmann (2005:53) dalam hal pengadaan barang dan jasa diperlukan ketaatan atas prinsip dasar, yang antara lain :

a. Efisien, yang berarti bahwa pengadaan harus diusahakan dengan sehemat mungkin.

b. Efektif, yang berarti bahwa pengadaan harus sesuai dengan kebutuhan yang telah ditetapkan dan dapat memberikan manfaat sebesar-besarnya.

c. Transparan, yang berarti bahwa pengadaannya harus bersifat terbuka.

d. Akuntabel, yang berarti harus mencapai sasaran, baik fisik,keuangan, maupun manfaat bagi kelancaran pelaksanaan operasional perusahaan.

Dari prinsip dasar yang dikemukakan oleh Puschmann (2005:58), ia menyimpulkan bahwa SOP yang digunakan untuk proses eprocurement memiliki dua jenis, antara lain : 


\section{a. Tanpa Menggunakan Sistem Tender (} hanya end user)

Dalam penggunaan SOP ini tidak menggunakan sistem tender, jadi end user atau pengguna akhir langsung melakukan pengajuan permintaan barang atau jasa menggunakan sistem e-procurement yang telah disediakan oleh perusahaan. Batasan efektivitas dalam metode ini yakni proses yang ada tidak rumit, 1) setelah persetujuan diterima oleh bagian keuangan, 2) proses pembelian dilakukan oleh bagian keuangan, dan 3) barang langsung diberikan kepada pengguna akhir. Kelemahan dari sistem ini adalah 1) sangat beresiko terjadinya penyelewengan jika permintaan dilakukan dengan budget yang besar dan 2) perusahaan tersebut harus memaksa bagian keuangan untuk bekerja lebih untuk membantu kelancaran proses pengadaan atau menambah divisi khusus untuk mengurusi pembelian barang.

\section{b. Menggunakan Sistem tender (vendor)}

Dalam penggunaan SOP ini menggunakan sistem tender. Jadi end user hanya diperbolehkan untuk mengajukan permintaan pengadaan pada e-procurement, dan untuk pembelian barang akan dilakukan oleh pihak vendor (yang telah memenangkan proses tender atau penunjukan langsung). Batasan efektivitas dalam metode ini adalah proses yang ada harus jelas (transparan), pengadaan harus sesuai kebutuhan, dan yang terpenting dokumendokumen pendukung pada proses Justifikasi Usulan Kebutuhan Belanja Barang ataupun jasa (JUKB) harus lengkap serta mendapat pengawasan yang baik dari pihak keuangan. Kelemahan dari sistem ini adalah 1) perusahaan harus cermat dalam memilih vendor, karna jika vendor tidak memiliki kualitas yang bagus mereka akan menjadi penghambat dalam proses pengadaan, dan 2) proses pengadaan memiliki waktu yang lebih lama dibandingkan metode tanpa tender.

\section{Sistem Informasi}

Informasi yang berkualitas adalah kebutuhan setiap perusahaan. Menurut Laudon (2004:8) sistem informasi mempunyai tiga aktivitas dasar yaitu:

1. input

Meliputi penerimaan dan pegumpulan data data mentah dari sumber internal perusahaan ataupun dari lingkungan luar perusahaan.

2. proses

Mentransformasi data - data mentah tersebut menjadi suatu bentuk yang berguna.

3. output

Memberikan informasi yang telah diproses kepada orang yang akan menggunakan atau ke sebuah aktivitas yang mungkin akan berguna.

Dan menurut O'Brien (2006:9) Sebuah sistem akan lebih berguna dengan menambahkan dua komponen tambahan yaitu :

1. feedback

feedback adalah data tentang performa sebuah sistem yang diberikan kembali ke pelaku sistem, yang digunakan untuk mengevaluasi atau memperbaiki input.

2. Control

Aktivitas yang dijalankan dalam control adalah memantau dan mengevaluasi feedback untuk mengetahui apakah sistem tersebut telah sejalan dengan tujuan yang dicanangkan.

Rahayu (2015) yang menyimpulkan penerapan sistem informasi akuntansi dalam pengolahan data pada PT Bank Perkreditan Rakyat Syariah Puduarta Insani Tembung sudah cukup efektif karena dapat menghasilkan inormasi yang cepat, tepat dan akurat sesuai dengan kebutuhan pihak manajemen. Sistem yang di terapkan sudah terintegrasi sedemikian rupa sehingga dapat menghasilkan beberapa output sekaligus/reporting internal dan eksternal. Namun adanya system yang terintegrasi ini maka entry data yang salah pada langkah awal akan mempengaruhi output pelaporan secara keseluruhan.

\section{Sistem Informasi Akuntansi}

Sistem informasi akuntansi (SIA) merupakan suatu rerangka pengkordinasian sumber daya (data, meterials, equipment, suppliers, personal, and funds) untuk mengkonversi input berupa data ekonomik menjadi keluaran berupa informasi keuangan yang digunakan untuk melaksanakan kegiatan suatu entitas dan menyediakan informasi akuntansi bagi pihak-pihak yang berkepentingan (Wilkinson, 1991). Setiap sistem informasi akuntansi melaksanakan lima fungsi utama, yaitu pengumpulan data, pemrosesan data, manajemen data, pengendalian data (termasuk security), dan penghasil informasi.

\section{Komponen Sistem Informasi}

sistem informasi yang akan dibangun, baik personal maupun multiuser, haruslah mengkombinasikan secara efektif komponenkomponen sistem informasi, yaitu: prosedur kerja, informasi (data), orang dan teknologi informasi (hardware dan software).

Gambar 2.1

Komponen sistem informasi

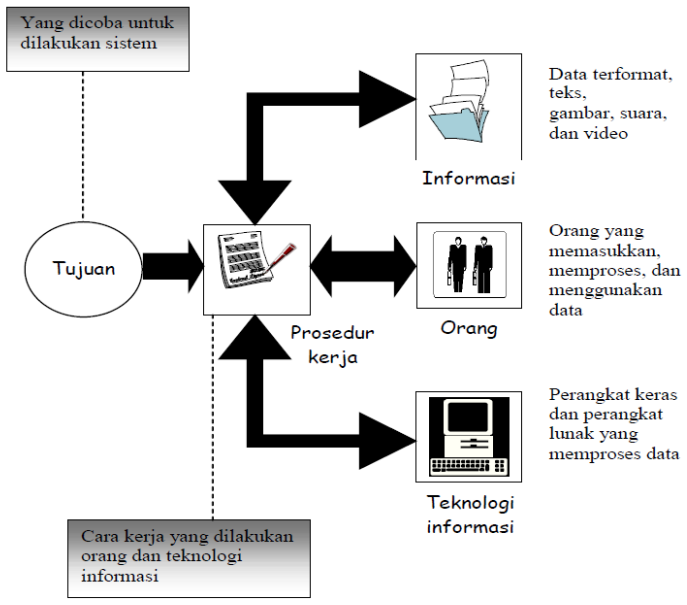

Sumber : Weber, Ron. 1999. Information System Control and Audit. P.894

\section{Evaluasi Sistem Informasi}

Ketika suatu sistem telah di implementasikan, maka operasional dari sistem tersebut akan terlihat. Namun untuk mengetahui bagaimana kerja sistem tersebut, perlu dilakukan suatu post implementation review pada sistem tersebut. O'Brien (2006:85) mengatakan "Therefore, the results of implementing a solution should be monitored and evaluated. This is called a post implementation review ". Dengan melakukan 
post implementation review perusahaan akan mengetahui apakah sistem telah berjalan sesuai dengan tujuan sistem pada awalnya.

\section{Efektivitas Sistem Informasi}

Evaluasi atas sistem informasi dilakukan untuk menentukan sebaik apa suatu sistem telah mencapai tujuannya (Weber, 1999;889). Dalam mengevaluasi suatu sistem, enam langkah yang dilakukan antara lain:

1. Mengidentifikasi tujuan sistem informasi tersebut

2. Memilih ukuran yang digunakan

3. Mengidentifikasikan sumber - sumber data

4. Menentukan nilai ex ante sebagai ukuran

5. Menentukan nilai ex post sebagai ukuran

6. Mengidentifikasi dampak system

\section{Faktor - faktor yang Mempengaruhi Efektivitas Sistem Informasi}

Badrudin (2015:41) menjelaskan bahwa kualitas sistem (system quality) dan informasi yang dihasilkannya (information quality) mempengaruhi persepsi pengguna (user) tentang kemudahan penggunaan sistem tersebut. Persepsi ini juga dipengaruhi oleh kepercayaan user itu sendiri akan kemampuannya dalam mengoperasikan komputer, tentunya dalam hal yang berhubungan dengan sistem tersebut secara kompeten (computer self-efficacy). Faktor ini muncul seiring dengan beralihnya tren sistem informasi dari manualized information system ke computer based information system (CBIS).

Persepsi user tentang kemudahan penggunaan sistem informasi akan tercermin dari bagaimana user tersebut menggunakan sistem informasi uang ada (information system use), termasuk di dalamnya intensitas dan bagaimana cara penggunaannya. Selanjutnya penggunaan sistem informasi tersebut akan berpengaruh pada kinerja user secara individual dalam organisasi. selain itu, penggunaan sistem tersebut akan berpengaruhjuga pada kepuasaan user atas sistem informasi itu sendiri (information system satisfication). Keduanya ini - kepuasaan dan dampak individual - juga akan saling berpengaruh satu sama lain. Pada akhirnya dampak individual ini akan berpengaruh pada kinerja organisasi secara keseluruhan.

Hasil penelitian Wahyuni (2015); Maslija (2016); Wulandari (2016) menyatakan bahwa sistem yang diterapkan di perusahaan kurang efektif, dikarenakan tidak adanya pemisahan fungsi dalam menangani catatan dan fisik persediaan. Sedangkan menurut aturan harus ada pemisahan fungsi antara bagian yang menangani catatan persediaan dengan bagian yeng menangani fisik persediaan. Selain itu perusahaan menunjukkan bahwasannya efisiensi sistem dan keamanan dari sistem menunjukkan bahwa sistem informasi persediaan dan pendistribusian barang belum berjalan dengan efektif.

Berbeda halnya dengan hasil penelitian Rahayu (2015), Nanoka (2014) menyimpulkan bahwa sistem yang berjalan pada proses servis perusahaan tersebut sudah berjalan dengan efektif, Meskipun dari ukuran-ukuran tersebut masih ada beberapa factor-faktor yang menjadi masalah, seperti Response time menurut para user memakan waktu 5 detik hingga 3 menit akan tetapi bisa mencapai 15 menit jika semua user membuka aplikasi terlebih ada user yang membuka aplikasi yang sama dalam waktu yang bersamaan pula. Ketidakstabilan sistem membuat membuat beberapa pekerjaan yang seharus-nya on target menjadi off target. Tercatat terdapat 3 pekerjaan dalam bulan pertama penelitian yang on target tapi sistem mencatatnya sebagai off target dan juga 3 (tiga) pekerjaan pada bulan kedua yang tercatat sebagai off target akan tetapi sebenarnya adalah on target. Para user merasa alur yang ada di SOP sangat panjang dan membingungkan karena itu mereka sering melanggar SOP yang sudah ada. Hal ini menurut mereka akan menghemat waktu dalam bekerja. Hal ini terjadi pada SA yang sering tidak membuat SIPP akan tetapi akan dibuat oleh part administrator dan juga pada SA dimana dia tidak melakukan clock off akan tetapi dilakukan oleh WSS.

\section{Kerangka Konseptual}

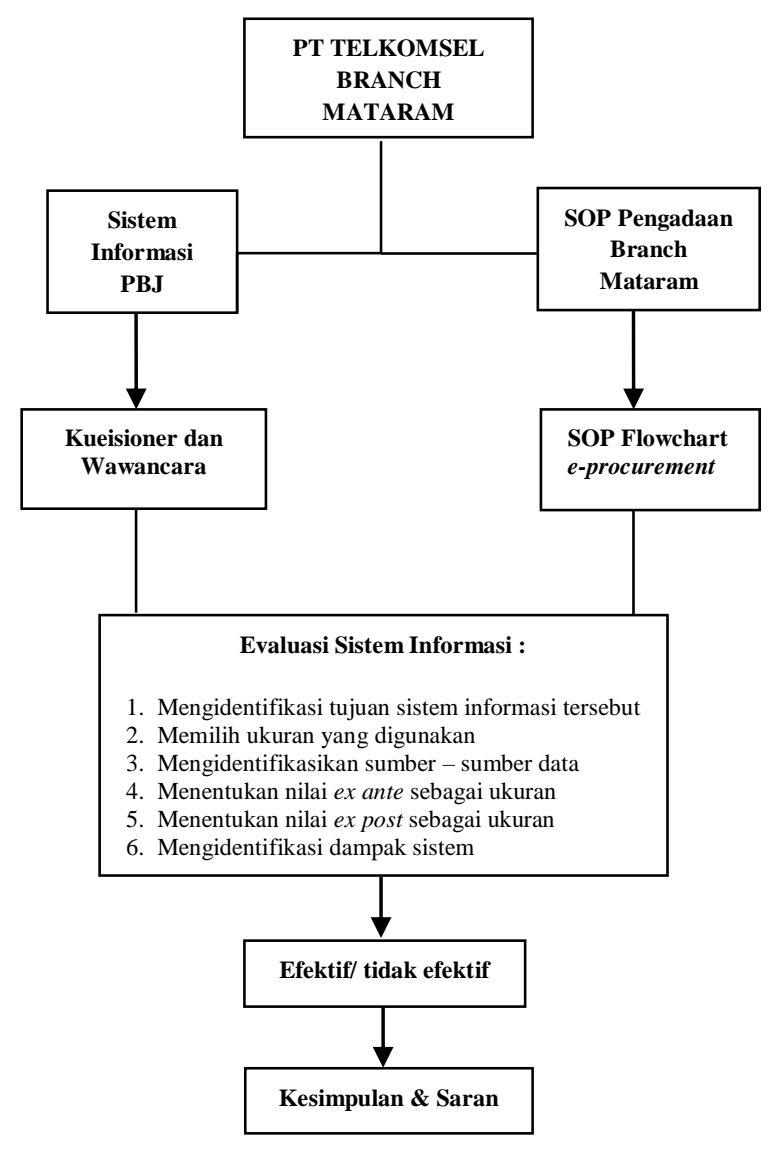

\section{METODE PENELITIAN}

\section{Jenis Penelitian, Populasi, Sampel}

Jenis penelitian yang digunakan dalam penelitian ini adalah penelitian deskriptif analitis, Populasi dalam penelitian ini adalah karyawan PT Telkomsel Branch Mataram, adapun sampel dalam penelitian ini ada dua macam yakni (1) pengguna sistem informasi yang berjumlah 45 orang, para pengguna system informasi pengadaan ini adalah karyawan tetap dari PT Telkomsel Branch Mataram. Dan sampel yang ke (2) struktur organisasi, SOP, BAK (Berita Acara Kesepakatan), FPB (Formulir Pemesanan Barang dan atau Jasa), BAST (Berita Acara 
Serah Terima) dan invoice, Faktur Pajak dan sumber lainnya yang mendukung penelitian ini.

\section{Instrumen Penelitian}

Dalam penelitian ini peneliti menggunakan indikator penelitian dari teori milik Weber (1999:893) yakni faktor-faktor yang mempengaruhi efektivitas sistem informasi. Dari ke Sembilan faktor yang ada peneliti hanya menggunakan 8 faktor, karena peneliti hanya meneliti sebatas dampak sistem terhadap user atau individu, tidak melebihi hingga dampak sistem terhadap organisasi. Indikator-indikator tersebut antara lain :

a) Kualitas system.

b) Kualitas informasi.

c) Manfaat yang dirasakan.

d) Persepsi kemudahan dalam penggunaan.

e) Keberhasilan computer terhadap diri yang menggunakan.

f) Penggunaan system informasi.

g) Dampak perorangan.

h) Kepuasan terhadap system informasi.

Ke delapan indikator diatas nantinya akan dijadikan sebagai acuan oleh peneliti untuk mengukur efektivitas sistem ke dalam bentuk kuesioner dan wawancara. Dan berikut adalah model perhitungan yang digunakan dalam menentukan persentase kuesioner :

a. System Quality $=\frac{\sum \text { user menjawab ' 'YA' }}{\sum \text { user }} \times 100 \%$

b. Information Quality $=\frac{\sum \text { user menjawab 'YA' }^{\prime}}{\sum \text { user }} \times 100 \%$

c. Perceived usefullness $=\frac{\sum \text { user menjawsb" } Y A "}{\sum \text { user }} \times 100 \%$

d. Perceived ease of use $=\frac{\sum \text { user menjawsb " } Y \text { Pa' }}{\sum \text { user }} \times 100 \%$

e. Computer Self-Efficacy $=\frac{\text { I war manjassb " "WX" }}{I \text { uasr }} \times 100 \%$

f. Information system use $=\frac{\mathbb{I} \text { war manjawzb " "WX" }}{\mathbb{I} \text { wasr }} \times 100 \%$

g. Individual Impact $=\frac{\sum \text { usermenjawab 'YA' }}{\sum \text { user }} \times 100 \%$

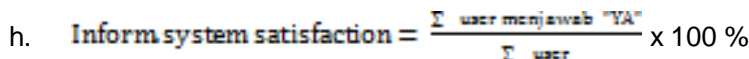

Dari tanggapan tiap user, penulis akan menganalisis tanggapan tersebut untuk mengetahui efektivitas sistem informasi yang telah diterapkan. Penulis akan membandingkan antara jumlah kumulatif tanggapan positif dengan tanggapan negatif dari user yang lebih banyak atau lebih dari $50 \%$. Jika tanggapan negatif lebih banyak maka sistem disimpulkan kurang efektif dan sebaliknya jika tanggapan positif lebih banyak maka disimpulkan sistem bekerja secara efektif. Penulis juga mengklasifikasikan perhitungan untuk masing masing ukuran evaluasi yang ada. Sehingga untuk masing - masing ukuran dapat diperoleh hasilnya yaitu efektif atau tidak. Untuk menghitung nilai masing-masing ukuran evaluasi peneliti menggunakan program microsoft excel 2007.

\section{Langkah-Langkah Penelitian}

Dalam penelitian ini peneliti memiliki langkah-langkah dalam melakukan proses evaluasi terhadap sistem yang berjalan di perusahaan yang akan diteliti untuk melihat efektifitas dari sistem yang telah diimplementasikan. Adapun langkah-langkah yang akan dilakukan oleh peneliti adalah sebagai berikut :

a. Mengidentifikasi tujuan sistem informasi tersebut (Identify the objectives of the information system).

b. Memilih ukuran yang digunakan (Select the measured to be used).

c. Mengidentifikasikan sumber - sumber data (Identify data sources).

d. Menentukan nilai ex ante sebagai ukuran (Obtain ex-ante value for measures).

e. Menentukan nilai ex post sebagai ukuran (Obtain ex-post value for measures).

f. Mengidentifikasi dampak sistem (identify the impact of system).

\section{HASIL PENELITIAN DAN PEMBAHASAN}

a. Mengidentifikasi tujuan sistem informasi tersebut

Sistem yang terangkum dalam sebuah standard ini telah dibuat sejak tahun 2005. Sistem ini bertujuan agar pekerjaan yang dilakukan berjalan lebih efektif. Efektivitas ini agar tujuan yang diinginkan tercapai. Untuk itu dibutuhkan sumber daya - sumber daya (resources) dengan tepat, resources tersebut adalah :

- People resources

Pengguna sistem pada perusahaan ini disebut end-users yang terdiri dari 45 orang, diantaranya satu orang Manager, delapan orang Supervisor, satu orang finance staff dan tiga puluh lima orang Marketing staff .

\section{- Hardware Resources}

Komputer - komputer yang digunakan untuk menunjang sistem ini telah disesuaikan spesifikasinya, yaitu: Processor (CPU) (Intel Pentium 4); Memori (2 Gb Ram); HDD (300 Gb); Input Devices (Keyboard, mouse); Output devices (Monitor)

- Software Resources

Software yang digunakan untuk menunjang operasional e-procurement pada di PT. Telkomsel Branch Mataram dapat dikelompokkan menjadi :

a) System software

Operating system : Windows 7 ultimate version 2010

b) Application software

Microsoft words 2010, excel 2010, powerpoint 2010, outlook express dan procurement online book. Procurement online book adalah custom application software yang dibuat untuk menunjang operasional e-procurement PT. Telkomsel Branch Mataram.

\section{Data Resources}

Data yang menjadi input sistem ini dimulai dari data PR (Purchase Requisition), OASIS, JUKB (Justifikasi Usulan Kebutuhan Barang dan jasa), serta KPA yang akan di upload ke procurement online book.

2. Network Resources

Suatu jaringan memungkinkan komputer komputer yang ada terhubung untuk mendukung pelaksanaan tugas masing - masing user. Jaringan dapat diklasifikasikan berdasarkan bentuk konfigurasinya (topologi). Topologi jaringan yang diadopsi oleh PT. Telkomsel Branch Mataram berbentuk bintang (star) yaitu 
konfigurasi jaringan yang terbentuk sedemikian rupa yang terdiri dari sebuah central host computer (server) yang terhubung pada sejumlah komputer yang lebih kecil (client).

\section{b. Memilih ukuran yang digunakan}

Langkah kedua yang dilakukan adalah memlih ukuran yang digunakan. Nilai dari masing - masing ukuran tersebut berdasarkan kuisioner yang telah dibagikan. Ukuran - ukuran tersebut adalah : (1). System Quality; (2) Information quality; (3) Computer self efficacy; (4) Perceived usefulness; (5) Perceived ease of use; (6) Information in us; (7) Individual impact; (8) Information system satisfaction.

\section{c. Mengidentifikasi sumber - sumber data}

Data yang diperoleh berasal dari responden yang merupakan user dalam sistem ini. Responden - responden tersebut adalah :

\section{Manager Branch}

Dalam sistem pengadaan barang dan jasa pada PT. Telkomsel Branch Mataram, Manager Branch adalah penanngung jawab secara keseluruhan. Jadi untuk segala jenis permintaan pengadaan barang dan jasa harus mendapat persetujuan dari Manager Branch.

\section{Supervisor Finance \& GA}

Setiap pengajuan permintaan pengadaan barang dan jasa harus mengikuti SOP yang ada pada perusahaan dan harus lengkap dalam proses administrasi, untuk itu supervisor Finance \& GA bertugas untuk memverifikasi setiap permintaan pengadaan dari user. Jika dari hasil pemeriksaan sudah lengkap maka permintaan tersebut baru bisa diproses, namun jika belum lengkap user diminta untuk memperbaiki atau melengkapi kembali persyaratan yang belum lengkap tersebut.

\section{Supervisor}

Supervisor adalah userl end userl pengguna akhir dalam proses dalam proses pengadaan barang dan jasa pada PT. Telkomsel Branch Mataram. untuk melakukan proses pengadaan ini, user harus mengikuti prosedur yang ada sesuai SOP.

\section{Staff Finance}

Dalam SOP pengadaan barang dan jasa pada PT. Telkomsel Branch Mataram dibutuhkan Staff Finance yang berfungsi sebagai administrasi untuk bertugas mengumpulkan permintaan pengadaan yang diajukan oleh pengguna akhir. Bagian administrasi ini adalah sebagai tahap seleksi awal user untuk mengajukan permintaan, jika dirasa telah lengkap maka akan diteruskan ke Supervisor Finance \& GA.

\section{Staff Marketing}

Staff Marketing sama halnya dengan Supervisor, yakni sebagai pengguna akhir. Yang dalam proses pengadaan barang dan jasa harus melakukan proses pengadaan sesuai dengan SOP yang ada.

\section{d. Menentukan nilai ex ante sebagai ukuran}

Sistem ini bertujuan untuk memberikan kemudahan dalam operasional pengadaan barang dan jasa mereka. Karena sebelum tahun 2010 sistem yang ada masih berjalan secara manual. Sistem yang telah diperbaharui adalah perombakan dari pengadaan manual menjadi sistem pengadaan yang berbasis $e$ procurement. SOP e-procurement pada PT. Telkomsel Branch Mataram digolongkan menjadi 3 jenis yakni, 1) pengadaan dibawah sepuluh juta rupiah, 2) pengadaan dibawah dua puluh juta rupiah, dan 3) pengadaan diatas dua puluh juta rupiah.. Ketiga SOP tersebut akan peneliti bandingkan dengan SOP yang sudah digunakan secara internasional untuk melihat apakah SOP pada PT. Telkomsel Branch Mataram sudah benar-benar menggunakan sistem e-procurement dan sesuai dengan SOP internasional. Untuk lebih jelasnya dapat kita lihat pada Lampiran 1.

Setelah peneliti mencoba membandingkan antara sistem pengadaan yang ada pada PT. Telkomsel Branch Mataram dengan SOP yang ada, akhirnya peneliti mengetahui bahwa sistem pengadaan yang berjalan sudah menggunakan sistem e-procurement dan telah sesuai dengan SOP. Dari perbandingan tersebut dapat diketahui bahwa pada PT. Telkomsel Branch Mataram menggunakan metode sistem tender. $\mathrm{Hal}$ ini juga dibuktikan dengan adanya dokumentasi dari data BAK, FPB, BAST serta invoice yang menunjukan bahwa perusahaan ini menggunakan vendor dalam proses pengadaan barang dan jasa. Dari uraian diatas dapat disimpulkan bahwa e-procurement yang ada pada PT. Telkomsel Branch Mataram telah berjalan dengan efektif. Penelitian ini didukung oleh penelitian Tanesia (2015) efektivitas pengadaan barang dan jasa secara elektronik memiliki tingkat efektivitas sedang dalam mengeliminir modus yang dapat menghadang perkembangan penggunaan anggaran pemerintah.

\section{e. Menentukan nilai ex post sebagai ukuran}

Pada bagian ini penulis mengumpulkan nilai untuk masing - masing ukuran efektivitas sistem yang berjalan. Nilai tersebut diperoleh dari hasil survey yang dilakukan dengan memberikan kuisioner kepada karyawan PT. Telkomsel Branch Mataram.

\section{- Evaluating System Quality}

Hasil kuisioner untuk faktor Response time, Turnaround system, stabilitas sistem, Kemudahan interaksi dengan sistem, Kegunaan dari fungsi yang diberikan oleh sistem, Kemudahan dalam pembelajaran sistem, Kualitas dokumentasi dan fasilitas bantuan sudah berjalan dengan efektif. Namun menurut $35 \%$ user memberikan tanggapan negatif untuk faktor kemudahan dalam pembelajaran system. Dari hasil wawancara yang dilakukan kepada para user tersebut mereka mengatakan bahwa mengalami kesulitan dalam mempelajari sistem e-procurement tersebut, di karenakan padatnya aktivitas mereka dalam pekerjaan sehari-hari yang tidak $100 \%$ berada di Branch.

\section{- Evaluating Information Quality}

Hasil kuisioner menunjukkan bahwa untuk kualitas informasi telah memadai dan dinyatakan efektif dengan nilai persentase $86 \%$. Akan tetapi masih ada satu faktor yang mendekati tidak efektif, yaitu faktor lengkap. Dalam faktor lengkap 38\% responden berpendapat bahwa informasi yang dihasilkan sistem e-procurement hanya menghasilkan informasi pengadaan barang dan jasa yang tidak sepenuhnya menghasilkan informasi sesuai bidang mereka.

Pada faktor - faktor lain seperti Autentik, Akurat, Unik dan tidak berlebih (nonredundant), Tepat waktu, Relevan, Komprehensif, Tepat, Padat, dan informatif menunjukan hasil yang efektif. Tanggapan positif yang diperoleh untuk faktor Autentik $87 \%$, faktor Akurat $89 \%$, faktor Unik dan tidak berlebih (nonredundant) $87 \%$, 
faktor Tepat waktu $84 \%$, faktor Relevan $89 \%$, faktor Komprehensif $80 \%$, faktor Tepat $86 \%$, faktor Padat $99 \%$, dan faktor informatif $99 \%$.

\section{- Evaluating Perceived Usefulness}

Tanggapan positif untuk evaluating perceived usefulness menunjukkan bahwa user merasa sistem berguna bagi pekerjaan mereka. Dari hasil kuisioner yang diperolah juga dapat dilihat bahwa sistem berjalan efektif dengan persentase $81,9 \%$. Enam pertanyaan yang diajukan dalam kuisioner saling terkait satu sama lain. Pada pertanyaan nomor 1, 3 dan 4 hasil yang diperoleh adalah $80 \%$, pada pertanyaan nomor 2 sebesar $87 \%$ sedangkan nomor 5 dan 6 berturut-turut sebesar $89 \%$ dan $76 \%$. Dari keenam pertanyaan ini bisa dilihat bahwa para user merasa sistem yang ada dapat meningkatkan kinerja, efektivitas dan produktivitas mereka.

Melalui pengamatan yang dilakukan, para user menjadi lebih fokus dalam menjalankan tugas mereka yang lain sesuai dengan bidang masing-masing. Karena penggunaan sistem eprocurement ini hanyalah faktor pendukug agar program marketing yang mereka buat berjalan dengan baik dan dapat mencapai hasil yang diinginkan. Jadi, jika sistem ini menjadi penghambat bagi mereka maka otomatis kinerja mereka tidak meningkat atau bahkan menurun.

\section{- Evaluating Perceived ease of use}

Tanggapan positif pada ukuran ini menunjukkan bahwa user merasa sistem mudah digunakan dan berjalan dengan efektif dengan persentase senilai $79,6 \%$. Tanggapan positif yang besar ini memang sejalan dengan pengamatan yang dilakukan oleh penulis. Meskipun tidak ada training khusus yang dilakukan untuk mempelajari sistem ini, namun para user cukup membaca pedoman atau buku panduan dalam menjalani sistem,dengan begitu para user bisa menjalankan aplikasi - aplikasi yang tersedia. Para user juga tidak perlu belajar terlalu lama karena memang sistem yang ada mudah untuk dipelajari dan mudah untuk digunakan.

\section{- Evaluating Computer self-efficacy}

Dari pertanyaan yang diajukan dalam kuisioner menunjukkan bahwa user merasa software yang ada telah tepat fungsinya. Hal ini sesuai dengan pengamatan yang dilakukan, software yang ada sangat cukup untuk membantu pekerjaan para user. Dan untuk sementara ini tidak perlu untuk menambah atau mengganti software yang baru.

\section{- Evaluating Information System Use}

hasil yang diperoleh menunjukkan para user memang menggunakan aplikasi - aplikasi yang ada sesuai dengan job description. Dari wawancara yang dilakukan $67 \%$ user mengaku telah mencoba semua aplikasi, dan sisanya mengatakan "tidak" karena tidak semua fungsi dalam sistem perlu untuk mereka ketahui. Kemudian hanya $62 \%$ user yang dapat menggunakan sistem ini tanpa bantuan orang lain, karena sebagian user merasa terlalu sibuk sehingga menggunakan jasa admin untuk menyelesaikan tugas mereka ini.

\section{- Evaluating Individual impact}

Hasil kuisioner menujukkan user tidak perlu waktu yang lama untuk membuat keputusan jika bekerja. Namun terdapat 2 faktor yang dirasa kurang berjalan dengan efektif, yakni kompensasi atau penghargaan yang didapat telah sesuai dengan tanggung jawab mereka
(53\% menjawab "ya") dan apakah suasana kerja telah memberikan kesempatan untuk bersosialisasi (40\% menjawab "ya"). Dari hasil wawancara yang dilakukan $47 \%$ user mengatakan bahwa jika pekerjaan mereka dilihat secara keseluruhan tidak sebanding dengan kompensasi yang diberikan perusahaan. Mengingat target dan tekanan yang diberikan oleh pihak perusahaan begitu berat terhadap mereka. Dengan suasana kerja yang tergolong berat ini juga membuat $60 \%$ user merasa kesulitan untuk bersosialisasi dengan karyawan lain di dalam perusahaan.

- Evaluating information system satisfaction

Pada ukuran ini tanggapan positif yang diperoleh menunjukkan bahwa para user merasa puas akan kinerja sistem sehingga menilai sistem telah bekerja dengan efektif dengan nilai persentase $60,6 \%$. Akan tetapi dari beberapa faktor dalam mengukur Information system satisfaction masih ada yang belum efektif seperti permintaan atas proses perubahan sistem dan level pelatihan sistem informasi yang diberikan kepada user.

Untuk faktor permintaan atas proses perubahan sistem hanya mencapai $29 \%$ saja. Hal ini sesuai dengan pengamatan yang dilakukan penulis bahwa tidak semua user bisa meminta perubahan untuk sistem yang telah ada. Yang dapat melakukan hal tersebut hanya Manager, Supervisor dan staff Finance \& GA.

Sedangkan pada faktor level pelatihan sistem informasi yang diberikan kepada user hanya mencapai $7 \%$. Para user memang tidak pernah diberikan pelatihan kecuali Manager, Supervisor Finance \& GA serta staff Finance \& GA sehingga user harus mencari tahu kegunaan dari fungsi - fungsi yang dipakai dengan mempelajari sendiri sesuai buku pedoman dan bertanya langsung kepada Supervisor atau staff Finance \& GA.

\section{f. Mengidentifikasi dampak system}

Pada tahap ini evaluasi sistem yang dilakukan diarahkan untuk pengambilan kesimpulan mengenai nilai - nilai yang didapat dari evaluasi yang dilaksanakan sebelumnya yaitu mengenai ex ante values for measures dan ex post values for measures. Pada tahap ini akan dibandingkan secara keseluruhan perbedaan antara nilai - nilai ex ante values for measures dan ex post values for measure. Dengan membandingkan dua hal ini bisa didapat kesimpulan dampak dari sistem terhadap perusahaan.

Dampak sistem terhadap kinerja perusahaan secara keseluruhan tidak bisa langsung dirasakan. Kinerja perusahaan tidak bisa dinilai dari penerapan sistem ini saja karena masih banyak faktor yang harus dipertimbangkan. Akan tetapi dengan penggunaan sistem ini sebenarnya bisa dilacak seberapa besar penyerapan budget yang telah dilakukan Branch Mataram, apakah telah sesuai target budget yang di anggarkan atau belum mencapai target. Hasil penelitian ini didukung oleh penelitian Tanesia (2015); Swadesi (2017) menunjukkan terciptanya optimaliasi anggaran dan waktu dalam proses pengadaan yang dilakukan sehingga terwujud proses pengadaan barang dan jasa yang efektif. 


\section{KESIMPULAN}

Dari hasil analisis penelitian pada PT. Tekomsel Branch Mataram, kesimpulan yang dapat ditarik adalah sebagai berikut :

a. Dari hasil kuesioner dan wawancara yang dilakukan dapat disimpulkan bahwa sistem informasi pengadaan barang dan jasa yang ada pada PT. Telkomsel Branch Mataram telah berjalan dengan efektif.

b. dengan membandingkan SOP yang ada pada PT. Telkomsel Branch Mataram dengan SOP yang sudah digunakan secara internasional, dapat disimpulkan bahwa sistem yang ada sudah sesuai dengan standar tersebut dan dinyatakan efektif. Dalam hal ini perusahaan tersebut menggunakan sistem tender dalam proses pengadaan barang dan jasa serta telah menerapkan sistem pengadaan $e$ procurement.

\section{DAFTAR PUSTAKA}

Badrudin. 2015. Dasar-dasar Manajemen. Alfabeta. Bandung

Laudon, Kenneth C., and Jane P. Laudon. 2004. Management Information system: Managing The Digital Firm. Tenth Edition. New Jersey: Prentice Hall, Inc.

McLeod, Raymond Jr and George Schell. 2001. Management Information system. eight edition. New Jersey: Prentice-Hall, Inc.

Mulyadi. 2016. Sistem Akuntansi. Yogyakarta: BPFE UGM.

Maslija, Noviani Iwai. 2016. Analisis Efektivitas Sistem Informasi Persediaan dan Pendistribusian Barang pada PT. Excelcomindo Pratama Tbk Cabang Medan.

Nanoka. Vondhy Prisviancho. 2014. Evaluasi Efektivitas Sistem Penjualan Servis Reguler Pada PT. ASTRA INTERNASIONAL - NISSAN DIESEL SALES OPERATION.

O'Brien, James. 2006. Management Information system: Managing Information Technology in The E-business Enterprise. Fifth edition. New York: McGraw-Hill Companies, Inc.

Puschmann, Thomas. 2005. Successful Use of eProcurement in Supply Chains: The
Information Management Group (IMG AG), St.Gallen.

Rahayu, Nurdin. 2015. Analisis Penerapan Sistem Informasi Akuntansi Dalam Pengambilan Keputusan Pada PT Bank Perkreditan Rakyat Syariah Puduarta Insani Tembung.

Sartono, Agus. 2010. Manajemen Keuangan, Yogyakarta : BPEE.

Setyawan, Joni. 1998. Pemeriksaan Kinerja. Edisi 1. Yogyakarta: BPFE Anggota IKAPI.

Swadesi, Utari (2017). Efektivitas Pengadaan Barang dan Jasa secara Elektronik (EProcurement) pada LPSE Kota Pekan Baru. Jom Fisip Volume 4 No.2 Oktober 2017.

Tanesia, Randy Kristovandy (2015). StudiEfektivitas Pengadaan Barang dan Jasa Pemerintah Secara Tradisional dan Elektronik. JurnalTeknikSipil Volume 13. No.2, April 2015 136-145

Wahyuni. 2015. Analisis Penerapan Sistem Komputerisasi Dalam Pengolahan Data Persediaan pada PT. Pertamina. UPMS-1 Medan.

Weber, Ron. 1999. Information System Control and Audit. New Jersey: Prentice-Hall, Inc.

Wulandari, Putri. 2016. Analisis Sistem Informasi Akuntansi Persediaan Secara Komputerisasi pada PT Amal tani.

http://barakbanten.com/berita-736-sistempengadaan-barang--jasa-bumn-perludibenahi.html.

http://hasagabo.blogspot.com/2010/11/sisteminformasi-akuntansi-pengertian.html.

http://elista.akprind.ac.id/staff/catur/SistemInformasi-Akuntansi/01aSIA\%20dan\%20teknologi\%20informasi. pdf.

http://www.wisegeek.com/what-isprocurement.htm. 